\title{
Rural Officials Discover the Printing Press in the Eighteenth-Century Habsburg Monarchy
}

\author{
Andreas Golob
}

In 1794, the widespread newspaper Graz Peasant News (Grazer Bauernzeitung) contained a peculiar announcement. In a mixture of baroque long-windedness and bureaucratic formulae, it told its readers that the local ruler, Count Dismas von Stubenberg, had convened all his "vassals" to renew their allegiance to him as their landlord. ${ }^{1}$ Published in the Graz Peasant News, the news of this feudal ritual could easily transcend the local sphere, and potentially reach subjects all over the Habsburg Monarchy, such as the craftsmen or soldiers belonging to the class at which the newspaper was aimed. This newspaper notice at one glance demonstrates the tensions between Enlightenment and feudal tradition that were inherent to the late eighteenth-century Habsburg Monarchy: while the rise of newspapers such as the Graz Peasant News was premised on Enlightenment ideals, the same newspapers reported on the renewal of feudal allegiances, a medieval ritual that was remarkably long-lived in rural Central Europe.

In the second half of the eighteenth century, Habsburg reforms aimed to deprive landlords of their longstanding, financial, judicial and social privileges to gain direct access to the rural population. ${ }^{2}$ This goal was not fully and permanently achieved until the revolution of 1848 . The most important, general and lasting achievement of the 178 os was the obligatory regulations of the special training for newly employed officials in all administrative spheres, including seigneurial estates. These administrators gradually replaced officials who

1 Leopold Xavier Löw (on behalf of Dismas Herr von Stubenberg), '1. Convoc. der herrlich von Stubenbergischen Lehensvasallen', Graz Peasant News (hereafter GPN) 49 (19 June 1794), [p. S5]. In case of non-paginated parts of newspapers, the page numbers are given in square brackets; 'S' in front of the page number stands for supplement ("Anhang"), 'A' for advertising supplement ("Beilage"). Peter Burke supplied the (literal) translation into "Graz Peasant News" used throughout this contribution, see Popular Culture in Early Modern Europe (Farnham/Burlington: Ashgate, 2009), p. 364.

2 Ernst Wangermann, From Joseph II to the Jacobin Trials. Government Policy and Public Opinion in the Habsburg Dominions in the Period of the French Revolution (Oxford: Oxford University Press, 1959), p. 3. 
had been trained on the job and who were increasingly seen as the weak links or even opponents of enlightened administration. This 'modern' professionalisation and specialisation which Habsburg central authorities forced upon feudal structures strengthened subjects' rights and, albeit very cautiously, curtailed the landlords' power.

This chapter investigates the relationship between the Enlightenment reforms of rural administration and the printing press, concentrating on those rural areas in which print had barely made an impact before the 178 os. On the basis of theoretical manuals and with the help of articles as well as advertisements in newspapers, I analyse how seigneurial clerks and civil servants in former monastic estates used print communication to reform rural administration. In doing so, this case study contributes to two fields of study. First, research in Central Europe, which also strove to include Italian Habsburg holdings and the Austrian Netherlands, has recently shown great interest in administrative practices in general, but the use of media in this field is still widely uncharted. ${ }^{3}$ Surveying the media use of seigneurial clerks and administrators of state properties is also rewarding for media history in general, because comparable analyses on the early-modern history of print tended to concentrate on higher ranking governmental, noble, clerical and municipal authorities or on urban representatives of the legal profession. ${ }^{4}$ The analysis also contributes

3 Thomas Winkelbauer, Robot und Steuer. Die Untertanen der Waldviertler Grundherrschaften Gföhl und Altpölla zwischen feudaler Herrschaft und absolutistischem Staat (vom 16. Jahrhundert bis zum Vormärz) (Vienna: Verein für Landeskunde von Niederösterreich, 1986), pp. 185-206 and 225-238; Thomas Winkelbauer, 'Instruktionen für Herrschaftsbeamte und grundherrliche Ordnungen in den österreichischen und böhmischen Ländern', in Josef Pauser, Martin Scheutz and Thomas Winkelbauer (eds.), Quellenkunde der Habsburgermonarchie (16.-18. Jahrhundert). Ein exemplarisches Handbuch (Vienna/Munich: Oldenbourg, 2004), pp. 409-426; Michael Hochedlinger and Thomas Winkelbauer (eds.), Herrschaftsverdichtung, Staatsbildung, Bürokratisierung. Verfassungs-, Verwaltungs- und Behördengeschichte der Frühen Neuzeit (Vienna/Munich: Böhlau/Oldenbourg, 2010); Anita Hipfinger etc. (eds.), Ordnung durch Tinte und Feder? Genese und Wirkung von Instruktionen im zeitlichen Längsschnitt vom Mittelalter bis zum 2o. Jahrhundert (Vienna/Munich: Böhlau/ Oldenbourg, 2012); William D. Godsey, The Sinews of Habsburg Power. Lower Austria in a Fiscal-Military State 1650-1820 (Oxford: University Press, 2018); Rachel Renault, La permanence de l'extraordinaire. Fiscalité, pouvoirs et monde social en Allemagne aux XVII ${ }^{e}-X V I I I^{e}$ siècles (Paris: Éditions de la Sorbonne, 2017).

4 Andrew Pettegree (ed.), Broadsheets. Single-sheet Publishing in the First age of Print (Leiden: Brill, 2017), esp. the chapters in part 3. Andrew Pettegree and Arthur der Weduwen, The Bookshop of the World. Making and Trading Books in the Dutch Golden Age (New Haven/ London: Yale University Press, 2019), esp. pp. 9, 313-314 (on the legal profession). As a rare exception to this rule: Elizabeth Andrews Bond, 'Science, Technology, and Reform in the French Countryside: The Role of Provincial Officials in the eighteenth-century Press', French History and Civilization, 7 (2017), pp. 39-5o. 
to the growing research on advertising papers, which usually contained official announcements. Studies in this field have focused on prominent official newspapers which represented central governments and their branches. Urban media enterprises have dominated scholarly discussions. ${ }^{5}$

Throughout the chapter, the Graz Peasant News will represent the periodical press. Like its competitors, this newspaper profited from the so-called 'extended freedom of the press'. This period of press freedom was shortlived as the War of the First Coalition (1792-1797) brought back a stricter press surveillance. ${ }^{6}$ Although its editor, Michael Hermann Ambros (1750-1809), could neither profit from personal wealth nor from any privileges, his newspaper survived ten years from 1786 to 1796 and even a ban from February to May 1792. The newspaper was highly regarded by contemporaries, and has been acknowledged by media historians as well. ${ }^{7}$ Although widespread in the Habsburg Monarchy as a whole, the stronghold of Graz Peasant News was Graz, the capital city of the Duchy of Styria. While Graz was the third largest city of the Habsburg Empire, the rest of the Duchy was mainly a rural province with some Alpine parts, which explains the newspaper's self-proclaimed agricultural identity. ${ }^{8}$ Styria's agricultural character reflects the situation of most of early modern Central Europe and can serve as a representative case study from both an administrative and editorial perspective.

5 Gerhardt Petrat, 'Das Intelligenzblatt - eine Forschungslücke', Presse und Geschichte, II (1987), pp. 207-231; Sabine Doering-Manteuffel, Josef Mančal and Wolfgang Wüst (eds.), Pressewesen der Aufklärung. Periodische Presse im Alten Reich (Berlin: Akademie Verlag, 2001); Pascale Cancik, Verwaltung und Öffentlichkeit in Preußen. Kommunikation durch Publikation und Beteiligungsverfahren im Recht der Reformzeit (Tübingen: Mohr Siebeck, 2007), part 2. Also see: Gilles Feyel, L'annonce et la nouvelle. La presse d'information en France sous l'Ancien Régime (1630-1788) (Oxford: Voltaire Foundation, 2000) and Andrew Pettegree, The Invention of News. How the World Came to Know About Itself (New Haven: Yale University Press, 2014), pp. $76-95$.

6 Thomas Olechowski, Die Entwicklung des Preßrechts in Österreich bis 1918. Ein Beitrag zur österreichischen Medienrechtsgeschichte (Vienna: Manz, 2004), pp. 89-104.

7 Heinrich K. Caspart, Michael Hermann Ambros. Ein österreichischer Journalist zwischen Aufklärung und Reaktion. Ein Beitrag zur österreichischen Mediengeschichte (2 vols. Vienna: Verband der wissenschaftlichen Gesellschaften Österreichs, 1991); Holger Böning, 'Grazer Bauernzeitung', in Holger Böning and Reinhart Siegert (eds.), Volksaufklärung. Biobibliographisches Handbuch zur Popularisierung aufklärerischen Denkens im deutschen Sprachraumvon den Anfängen bis 1850, vol. 2: Der Höhepunkt der Volksaufklärung 1781-1800 und die Zäsur durch die Französische Revolution (Stuttgart/Bad Cannstatt: Frommann-Holzboog, 20o1), cols. 427-428; Burke, Popular Culture in Early Modern Europe, p. 364.

8 For an outstanding, predominantly topographical, but also factual description from the period of interest see:Joseph Carl Kindermann, Repertorium der Steyermärkischen Geschichte, Geographie, Topographie, Statistik und Naturhistorie (Graz: Miller, 1798). 
In what follows, I will first outline the governmental and administrative spheres in Habsburg Styria, before proceeding to the analysis of the role of print in the Austrian administration. Thereafter, I will sketch how print was adopted to establish a canon of administrative literature and to create a forum for the exchange of ideas in the profession. The chapter will also show how bureaucrats used Graz Peasant News to manage their tasks, and how they represented themselves in media. Finally, I will discuss both the editor's commitment to the government (and through that to his own profits), and his cautious criticism of the shortcomings of rural administration in the Habsburg Empire.

\section{At the Forefront of Administration: Generalists in Print}

Two spheres of power still co-existed and competed in late eighteenth-century Habsburg Styria. Landowners dominated the Styrian Estates that consisted of clergy, peers, knights and a small, disproportionate representation of the towns. Exerting their financial, judicial and social power over their subjects, the landlords maintained their own governmental and administrative structures which came into conflict with Habsburg attempts to strengthen central government and administration. This conflict had already escalated in the struggle between Protestants and Catholics. ${ }^{9}$ Although the Habsburgs had overcome opposition in the Estates and had rigorously recatholicised the country by the early seventeenth century, the landlords' position remained strong. Around 168o, legislative action tried to assist peasants and to instrumentalise them to attack ruthless seigneurs. ${ }^{10}$ However, these laws were rarely fully executed until Maria Theresa introduced new administrative structures in 1749. All dominions, except for the Austrian Netherlands and Hungary, received a regional authority called "Repräsentation und Kammer" and renamed "Gubernium" in 176o." These branches of the Habsburg central government served as pivots between the court and its decisions on the one hand and the lowest executive level of the counties ("Kreise") on the other. Civil servants in the county administrations eventually advocated legislation in favour of peasants and attracted the landlords' resentment. Seigneurial officials were finally obliged to undergo

$9 \quad$ Regina Pörtner, The Counter-Reformation in Central Europe. Styria 1580-1630 (Oxford: Oxford University Press, 2001), on the role of print esp. consult pp. 216-217.

10 Erich Zöllner, Geschichte Österreichs. Von den Anfängen bis zur Gegenwart (Vienna/ Munich: Verlag für Geschichte und Politik/R. Oldenbourg, 199o), pp. 279-28o, 314-315.

11 Between 1784 and 1791, Graz was the seat of a Gubernium not only for Styria, but also for Carinthia and Carniola. 
specialist, formal, at least semi-academic training. Officials in larger seigneurial entities were even instructed to perform tasks for the central government, when new recruiting districts ("Werbbezirke") were established since $1770 .{ }^{12}$ Private landlords had actually hired as well as paid these men to serve them in the first place. Besides, however, they also had to care for a wide range of state-administrative affairs like taxation, recruiting or requisitioning. This shows how closely the two spheres were entangled.

Both spheres of government and administration in Styria began embracing print in the sixteenth century by publishing laws, instructions and propaganda. Viennese printers produced the first printed legislative documents of the central government for Styria. In the 1550s, the Styrian Estates profited from print as a means to push their political agenda. Eventually, the Habsburg authorities seized control in 1585 by appointing a court printer who would be given an exclusive privilege in 1600 . This monopoly contributed to the victory of Counter-Reformation, and was vigorously defended until the advent of Josephinian reforms. Only in 1780, after the court printer lost his privileges, was it possible to establish other print shops in the region..$^{13}$ The tightly controlled printing press in Styria had an effect on the periodical press. The first printed, regularly issued newspaper which also communicated legislative steps as an integral part of the news section dates from $1639 .{ }^{14}$ Government advertisements and other official announcements are absent in the Austrian newspapers before the 1720s, when the Viennese Diary (Wiener Diarium) became the dominant advertising newspaper in the Habsburg Monarchy. ${ }^{15}$ Due to demographic growth and its central position in regional administration and supra-regional commerce, the municipality of Graz began to use the periodical press in the mid-1740s. In the mid-176os, other municipalities, especially those where county administrations had their seats, followed suit. Beyond Graz,

12 Especially for Styria, but also applicable to the whole Habsburg Monarchy: Manfred Straka, Verwaltungsgrenzen und Bevölkerungsentwicklung in der Steiermark 1770-1850. Erläuterungen zur ersten Lieferung des Historischen Atlasses der Steiermark (Graz: Historische Landeskommission für Steiermark, 1978), pp. 28, 31-33. See Winkelbauer, Robot, pp. 211-219 (also on advantages for landlords who could get rid of renitent subjects through recruitment into the army).

13 Anton Durstmüller, 500 Jahre Druck in Österreich. Die Entwicklungsgeschichte der graphischen Gewerbe von den Anfängen bis zur Gegenwart, vol. 1: 1482 bis 1848 (Vienna: Hauptverband der Graphischen Unternehmungen Österreichs, 1981), pp. 31, 38, 76-83, 164-170, 349-353.

14 Durstmüller, 5ooJahre Druck, p. 164.

15 Walter Uibelacker, 'Die Entwicklung des Anzeigewesens in der Wiener Presse 1703-1848', Jahrbuch des Vereines für Geschichte der Stadt Wien, 2 (1940), p. 28. For Styria, consult the volumes 1721, 1745, 1746, 1765 and 1778 of the Graz Mercury (Grazer Merkur). 
in the countryside, authorities were hardly interested in using the press as a means of communication. Only a tiny minority of the administrators of large seigneurial estates did so in the late 1770 , and the still prominent monastic estates, even the most economically important ones, entirely eschewed the periodical press in conducting their administrative business.

Yet things began to change around the turn of the century, when the professionalisation of rural administration went hand in hand with an increase in the use of print. The rise of printed professional manuals is one sign of this change. Written by experienced peers, such manuals demonstrate the wide scope and complexity of everyday administrative business. In Styria, the head of the county of Graz ("Kreishauptmann"), Christoph von Schwitzen (1755-1796), compiled such a manual in 1787. Unsurprisingly, Von Schwitzen was a representative of the Habsburg authorities, who used the printed book to educate the autodidacts in seigneurial administrations. His handbook encompassed diverse entries dealing with procedures of civil as well as criminal law, with military affairs, policing, and almost every conceivable aspect of everyday life such as rural economics, healthcare and accounting, and even proto-psychological methods to explain laws or governmental needs to ordinary people. ${ }^{16}$ To accomplish all these tasks, officials had to be confident in their use of formal, correct and plain German. ${ }^{17}$ In 1805, Cajetan Wanggo (1762-1823) published a manual in which he added recent legislation to the already wide range of information provided by Schwitzen. ${ }^{18} \mathrm{~A}$ seigneurial clerk himself, Wanggo regretted that his predecessor had neglected the important aspect of seigneurial administration of justice, which was carried out by landlords and their officials. ${ }^{19}$ Intriguingly, he did not only recommend technical literature in this field, but also psychologically and socially revealing criminal stories, compiled and literarily framed by August Gottlieb Meißner (1753-1807). ${ }^{20}$

In subsequent years, Wanggo became one of the busiest Styrian authors, with an impressive list of well-received publications. Even during his early

16 Kristoph Schwizen, Versuch einer Anleitung für Junge Herrschafts-Beamte in Oesterreich, zur Kenntnis einiger der besten Bücher die von den Hauptgegenständen einer Herrschaftsverwaltung handeln (Graz: Widmanstetter, 1787), pp. 8-9.

17 Schwizen, Versuch einder Anleitung, p. 7 .

18 Cajetan Wanggo, Anweisung zur Kenntniß einiger der besten Geschäftsbücher, für angehende Beamte in österreichischen Herrschafts-Kanzelleyen auf dem offenen Lande (Graz: Tanzer, 1805), pp. v-VI.

19 Wanggo, Anweisung zur Kenntniß, pp. V-VI.

20 Wanggo, Anweisung zur Kenntni $\beta$, p. 34. For Meißner: Alexander Košenina (ed.), August Gottlieb Meißner, Ausgewählte Kriminalgeschichten. Mit einem Nachwort (St. Ingbert: Röhrig Universitätsverlag, 2004). 
career, he ranked prominently among Styrian-born writers. ${ }^{21}$ His career is a reminder that administrators in these years joined established publishing professionals, such as clerics and scholars, as published authors. About two dozen of Wanggo's colleagues, most of them his contemporaries, published at least one book. Not all of these seigneurial and civil servants became known for their specialist publications. Some of them began their artistic career in private or state administrative service. Examples include Franz Xaver Hysel (1770-1841), who eventually became an important figure in the local musicians' scene as a composer and music teacher, and the playwright Johann von Kalchberg (17651827), also editor of Graz Citizen News (Grätzer Bürgerzeitung).

The changing relationship between print and rural administration caused a generation gap, which increased towards the end of the eighteenth century. Schwitzen complained that older officials often opposed using printed aids. Instead, they preferred procedures they had learned on the job and which had been practiced for ages, following the same 'jogtrot'. For Schwitzen, alluding to a successful contemporary satirical novel featuring an all too compliant judge, such conservatism only produced "Schlendrianisten" (dawdlers). ${ }^{22} \mathrm{He}$ did, however, recognise the problems of introducing print in the education of officials. Adequate and useful instructional books were often too expensive. Therefore, the experienced administrator proposed book sharing, and did not shy away from recommending cheap, unauthorised reprints of original works published in the German cities. ${ }^{23}$ Schwitzen's propagation of print did not fall on deaf ears. Roughly fifteen years later, no fewer than 192 colleagues subscribed to Wanggo's manual on procedures in recruiting districts. In 1818, the second edition even attracted 356 subscribers. ${ }^{24}$ Around this time,

21 Johann Baptist von Winklern, Biographische und litterärische Nachrichten von den Schriftstellern und Künstlern, welche in dem Herzogthume Steyermark geboren sind, und in, oder außer demselben gelebt haben und noch leben. In alphabetischer Ordnung. Ein Beytrag zur National-Litterärgeschichte Oesterreichs (Graz: Ferstl, 1810). Winklern's scope neglected for instance teachers who often came to Styria from another region of the Habsburg Monarchy. They played an important role in Styrian-based (!) literature, as well, see the extensive bibliography in: Walter Pietsch, Die Theresianische Schulreform in der Steiermark (1775-1805) (Graz: Pädagogisches Institut in Steiermark, 1977), pp. 245-263. In Winklern's compilation clerics are clearly overrepresented, probably due to the compiler's predominant use of ecclesiastic networks to receive information.

Schwizen, Versuch, preface (not paginated). He referred to: [Franz Xaver Huber] Herr Schlendrian, oder der Richter nach den neuen Gesezen. Ein komischer Roman (Berlin: s.n., 1787). See Leslie Bodi, Tauwetter in Wien. Zur Prosa der österreichischen Aufklärung 17811795 (Vienna/Cologne/Weimar: Böhlau, 1995), pp. 296-311.

23 Schwizen, Versuch, preface, pp. 31, 11, 20-27.

24 Cajetan Wanggo, Practische Anleitung die Werbbezirks-Geschäfte in Oesterreichs deutschen Erblanden nach Vorschrift der ergangenen Gesetze zu besorgen. Ein Handbuch zum 
Styria's rural bureaucracy seems to have embraced the possibilities of print to communicate within the profession.

In the administration's communicative practices to a general audience, too, the 178 os saw a breakthrough of periodical print. Two ordinances imposed procedures which had been exercised in large municipalities of the Habsburg Monarchy before the $178 \mathrm{os}$, but in the rural context these procedures were almost completely new. In bankruptcy proceedings, threefold notifications via printed media became obligatory by a decree of $14 \mathrm{June} 1784 .{ }^{25}$ Two years later, the public auctions that might result from such cases had to be announced in the same way. ${ }^{26}$ By using print, absent creditors could be reached and the circle of prospective bidders widened, and consequently competition as well as gains would increase. For the local population, announcements would have to be posted at three different prominent locations if the auctioneer considered it useful. ${ }^{27}$ These locations had to be watched to avoid vandalism. In inheritance cases, too, the periodical press was on the rise, but on a voluntary basis. Searches for heirs and rightful claimants of all kind (for instance of bonds) through printed adverts became common in the 178 os. $^{28}$

The problems and limitations associated with the practice of communicating official announcements in print were also critically evaluated. Before the legislative steps discussed above, regular practice had already revealed problems. It proved to be risky, for instance, to summon an accused person via the newspapers. Privacy matters were at stake, and the person summoned had the right to complain if a more discrete way of reaching them would have been possible. ${ }^{29}$ One manual cited a real case which featured a claimant

Gebrauche für die dermahligen Vorsteher der ländlichen Bezirks-Commissariate, und zugleich ein Hülfsbuch für jene, welche einst bey diesen Ämtern angestellt zu werden wünschen (Graz: Tanzer, 180o). Second edition in 1818. Both editions offer detailed subscription lists.

25 Johann Nepomuk Neuhold, Praktische Einleitung zum allgemeinen in allen k. k. österreichischen Erblanden, im Königreich Hungarn, und den damit vereinten Provinzen bestehenden Verfahren in Rechtssachen, vol. 2 (Graz: Leykam, 4th edition, 1787), pp. 15-16, and for the Hungarian lands p. 155 .

26 N.N., Dritter Nachtrag und Fortsetzung des vermehrten Handbuches der Gesetze und landesfürstlichen Verordnungen vom ersten May 1786 bis ersten May 1787 (Graz: Miller, 1787), pp. $245^{-246 .}$

27 Johann Sigmund Rizy, Anmerkungen zur allgemeinen Gerichtsordnung für Böheim, Mähren, Schlesien, Oestereich ob und unter der Enns, Steyermark, Kärnthen, Krain, Görz, Gradiska, Triest, Tyrol, und die Vorlande, und zur allgemeinen Konkursordnung für eben diese k. k. teutschen Erbländer, vol. 2 (Vienna: Hörling, 1786), pp. 106-107 and N.N., Dritter Nachtrag, p. 246.

28 Neuhold, Praktische Einleitung, vol. 1, pp. 204-205.

29 Rizy, Anmerkungen, p. 143. 
who argued that a newspaper announcement could not have reached him during his absence abroad in the 1760 s. Instead of publishing a newspaper announcement, he argued, the authorities should have traced his route by observing the passports he had obtained. On this basis, the case was indeed reviewed in $1791 .^{30}$

The impact of newspaper announcements was still disputed in the $178 \mathrm{os}$ after the geographical spread of newspapers had improved and the density of their network in the Habsburg dominions had increased considerably. Optimistic advocates of announcements in the periodical press could also point to the educational reforms of the mid-1770s which had already brought some success, even in rural areas. ${ }^{31}$ An anonymous follower of the Habsburg 'chief administrator' Joseph von Sonnenfels (1732-1817) admitted that the Austrian style of announcements was certainly not perfect, but he was convinced that it was clear as well as plain enough to be understood even by peasants. In this respect, examples in Vienna News (Wiener Zeitung) compared favourably to newspapers of Hamburg or Jena, which would be cluttered with Latin expert terminology. ${ }^{32}$ However, more pessimistic authors doubted whether newspapers could successfully inform peasants about legal action, especially in more mountainous settings. ${ }^{33}$

\section{Administrative Announcements in the Periodical Press}

Announcements consisted of formulas in a specific bureaucratic German. They followed models given in the aforementioned manuals, communicated deadlines for claims and potential losses which would result from missed deadlines. ${ }^{34}$ These phrases guaranteed reliance and linked practices to the underpinning laws. ${ }^{35}$ A negative effect of this practice was that announcements became quite long-winded, even when they used more 'modern' and plain formulae. It

30 Christoph von Keßler, Theoretisch-praktischer Unterricht für angehende Beamte, und für Jene, die Geschäfte bey den Stellen zu betreiben haben (Vienna: Gräffer Jr., 1791), pp. 324, 328.

31 Pietsch, Schulreform, pp. 48-54, esp., 52.

32 N.N., Anhang zu dem Werke über den Geschäftsstil des Hrn. Hofraths und Professors von Sonnenfels. Herausgegeben von einem seiner Zuhörer (Vienna: Kurzböck, 1787), p. 124.

33 Georg Scheidlein, Erklärung des Oesterreichischen Provinzialrechtes, vol. 1 (Vienna: Gassler, new and revised edition, 1804), p. 40.

34 E.g. Alois Senitzer (on behalf of Aflenz State Property), 'Vorladung', GPN 1 (3 January 1791), [p. S2]. St. Lambrecht State Property, 'Citatio der Johann Georg Dietmayrschen Gläubiger', GPN 12 (10 February 1791), [p. S5].

35 Especially with reference to the legal system of the Habsburg hereditary lands: Karl Johann Marx (on behalf of Herberstein Seigneury), 'Vorrufung der Anton Müllerischen Gläubiger', GPN 82 (13 October 1791), [pp. A3-4]. 
is interesting to note that these advertisements were as elaborately designed as the rest of the newspaper text. Professional terms in Latin were principally printed in Roman typeface. Fraction numbers might also be printed with special types, and sometimes even square measures were specially marked. These characters and symbols could be principally found in sample books for the production of calendars. ${ }^{36}$ Pragmatically, mere amendments at the bottom of the original notice announced further or extended deadlines. ${ }^{37}$ Repeated announcements which needed money and working time showed how committed and reliant officials were. ${ }^{38}$ In most cases, only the relevant office is eventually given as a reference. Seigneurs seldom signed announcements themselves, as for instance Count Herberstein did when he reminded merchants and artisans that his recently deceased janitor had not been allowed to act as an agent for financial transactions and mentioned a lawyer as a contact person for pending payments and future contracts. ${ }^{39}$ The advertisements, however, displayed a considerable number of clerks who self-consciously added their name at the end of their notifications. In Graz Peasant News, 38 civil servants of state properties and seigneurial clerks came into public view this way.

Cooperation between different branches of administration proved to be necessary due to overlapping boundaries of seigneuries, parishes and state authorities. This was especially the case for different types of auctions. Deadlines and time-consuming correspondence within the awkward administrative system had to be taken into account. No fewer than three ecclesiastical and five secular seigneuries were involved, for instance, when vineyards, situated near Maribor in Southern Styria and belonging to the ecclesiastical authority of St. Andrä in Carinthia, were sold. ${ }^{40}$ Rarely, newspapers were explicitly mentioned as a means to execute business. ${ }^{41}$ In one case, the commissioner regretted that there was no interest despite his announcement in Graz Peasant

$36 \quad$ E.g.: Johann Nep[omuk] Painsipp (on behalf of Burgau Seigneury), 'Licit. Jos. und An. Wagnerisches Haus etc., Graz News (“Grätzer Zeitung”, hereafter: GN), 6o (26 July 1791), pp. 1215-1216; cf. the last page of this non-paginated catalogue of types: Wenzel Johann Crabat, Specimen Characterum Latinorum Existentium in Pragensi Typorum Fusura (Prague: Crabat, 1761).

37 Alois Senitzer (on behalf of Aflenz State Property), 'Licit. Aloys Klinzische Realitäten', GN 6o (26 July 1791), p. 1216.

$38 \quad$ E.g.: St. Martin Seigneury, 'Edikt', GPN 61 (1 August 1791), [pp. S5, A3] and again $G P N 79$ (3 October 1791), [pp. A1-2] (Johann Muhr; Joseph Eißner; Mathias Tillinger).

39 Johann Gundacker Graf zu Herberstein, 'Erinnerung an Handelsleute und Professionisten', GPN 55 (11 July 1791), [pp. A1-2].

40 Franz Xaver Radetzi (on behalf of Maribor Parish Church), 'Weingärten zu verkaufen', GPN 71 (5 September 1791), [p. S6].

41 Jakob Mittersdorf (on behalf of the Market Town of Gleisdorf), 'Edikt', GPN 20 (10 March 1791), [p. S4]. 
News. ${ }^{42}$ Exceptionally as well, collaboration with an inquiry office can be traced. ${ }^{43}$ Some clues in obligatory announcements about bankruptcy proceedings also point at informal communication between officials and creditors. An administrator, for instance, advised creditors to mediate meagre charges instead of launching the complex and expensive official procedure which would have considerably reduced the bankruptcy assets. ${ }^{44}$ On the other hand, creditors' requests were taken into account when an official allowed an unusual fourth session for an auction. ${ }^{45}$ The highly public procedure in bankruptcy matters obviously also generated a public stigma, because debtors' failures became widely known and because their property was on display. Indirectly, this assumption might be ascertained by the wording in the announcements of voluntary liquidations, which probably aimed at making a living after professional life. Auctioneers of this kind were anxious to stress their voluntary decision prominently, even right at the beginning of the notification. ${ }^{46}$

Inheritance cases are most elucidating when it comes to the necessity of voluntary, public, wide-reaching announcements. Travelling artisans, merchants, pilgrims, and particularly soldiers provided examples for professional, voluntary or forced mobility. ${ }^{47}$ The latter were the most prominent category due to the last Austro-Ottoman War, waged between 1788 and 1791. Especially Graz Peasant News played an extraordinary part in this confrontation as a leading "war newspaper", composed on the basis of about eighty correspondents along the frontline, and read in field camps as well as garrisons. ${ }^{48}$ In many cases, this

42 Market town of Gleisdorf, 'Lizitazion', GPN 27 (4 April 1791), [p. A4]. More general on the periodical press and on the tedious work of publication in a time of bear markets during exhausting wartime in the same, still undetermined case: Idem, 'Lizitazion', GPN 37 (9 May 1791), [pp. A3-4].

43 Pirkwießen Seigneury, 'Eine Mauthmahlmühle in Bestand zu verlassen', GPN 15 (21 February 1791), [p. S8].

44 Anton Alois Königshofer (on behalf of Feistritz Seigneury), 'Konvokazions-Edikt', GPN 58 (21 July 1791), [pp. S2-3].

45 Johann Zechner, Sebastian Lang and Ignaz Brunader (on behalf of the market town of Weiz), 'Edikt. Lizit. Johann Strohmayrisches Haus samt Bäkensgerechtigkeit', GPN 6o (28 July 1791), [pp. A2-3].

46 E.g. Gottlieb Anton Aust (on behalf of Wolkenstein Seigneury in Irdning), 'Verkauf eines Färberhauses, und dazu gehörigen Gründen', GPN 17 (28 February 1791), [p. S7].

47 E.g.: Franz Wolfgang Marx (on behalf of Eggenberg Seigneury), 'Vorrufungs Edikt', GPN 55 (11 July 1791), [p. S8]; St. Martin Seigneury, 'Edikt', GPN 61 (1 August 1791), [p. A3] (Joseph Eißner): a commoner missing on his journey to Rome (!); St. Marx Seigneury in Dornau, 'Vorrufungs-Edikt', GPN 24 (24 March 1791), [p. S5] (Gregor Kollaritsch).

48 Andreas Golob, 'Die Grazer Bauernzeitung - eine 'vergessene' "ungarsche Provinzialzeitung"? Ein Mosaikstein zur Zeitungsgeschichte Ungarns am Ende des 18. Jahrhunderts', Magyar Könyvszemle, 131:1 (2015), pp. 25, 35. 
category of searches for individuals may also be interpreted as an attempt to pronounce the absent person dead to finalise the inheritance procedure, particularly when individuals were missing for over 33 years. ${ }^{49}$ Sometimes, they demonstrate how wars separated family members and probably left a multitude of orphans behind..$^{50}$ Information on the missing person was often scarce, however, even though officials sought to offer 'right and reliable' information and used internal as well as external channels to close the cases correctly. ${ }^{51}$ Relatives were not always informed about where their absent family members were, and hearsay played a considerable role. ${ }^{52}$ In some notifications, some details and their sources emerge: places of recruitment were given, and the consulted relatives were listed. ${ }^{53}$ An administrator of a state property, for example, found out that forty years earlier (!) a veteran had sent his two minor sons to a subject of a monastery that became state property in 1785 . Even the sons' professions were recorded. ${ }^{54}$ In another case, two known steps in a clerk's career were cited. ${ }^{55}$

Similarly, information on auctions of natural produce and lease contracts highlight the officials' remarkable responsibility in both the private and state economy. Since these announcements were usually shorter, they were also cheaper to place (see below). The use of print media in these cases also led to confrontations with local tenants. They had to face formerly unknown supra-regional competition, especially as far as lease contracts were concerned. As a compromise, option rights for the bidders from the surrounding area could be granted if they (probably joining efforts) succeeded to match the highest offer. ${ }^{56}$

49 E.g. St. Lambrecht State Property, 'Citatio Balthauser Fritz', GPN 47 (13 June 1791), [p. S7].

$50 \quad$ E.g. Joseph Eugen Weiß (on behalf of Gleichenberg Seigneury), 'Citat. der Gebrüder Jakob, und Michael Klement', GPN 27 (4 April 1791), [p. A3]; St. Martin Seigneury, 'Edikt', GPN 61 (1 August 1791), [p. S5].

$5^{1}$ Franz Joseph Mlaker (on behalf of Pfannberg Seigneury), 'Convocation', GPN 10 (3 February 1791), [p. S4].

52 E.g. Marx, 'Vorrufungs Edikt'. Franz Xaver Rigler (on behalf of Neuberg an der Mürz State Property), 'Vorruffungs-Edikt' [sic!], GPN 7 (24 January 1791), [p. S8]: "as rumour has it”.

53 St. Marx Seigneury, 'Vorrufungs-Edikt'.

54 Joseph Hoffer (on behalf of Pöllau State Property), 'Kundmachung', GPN 95 (28 November 1791), [pp. S7-8].

55 Johann Dominik Krescher (on behalf of Pleterje State Property), 'Vorrufung des Franz Mlacker', GPN 1 (3. January 1791), [p. S2].

56 Esp. State-Property Administration in Rottenthurn, 'Getreidzehend-Versteigerung von der k. k. Staatsherrschaft Steinhof', GPN 22 (19 March 1795), [p. A1]. 
TABLE 4.1 Official announcements in Graz Peasant News, 1791 and 1792

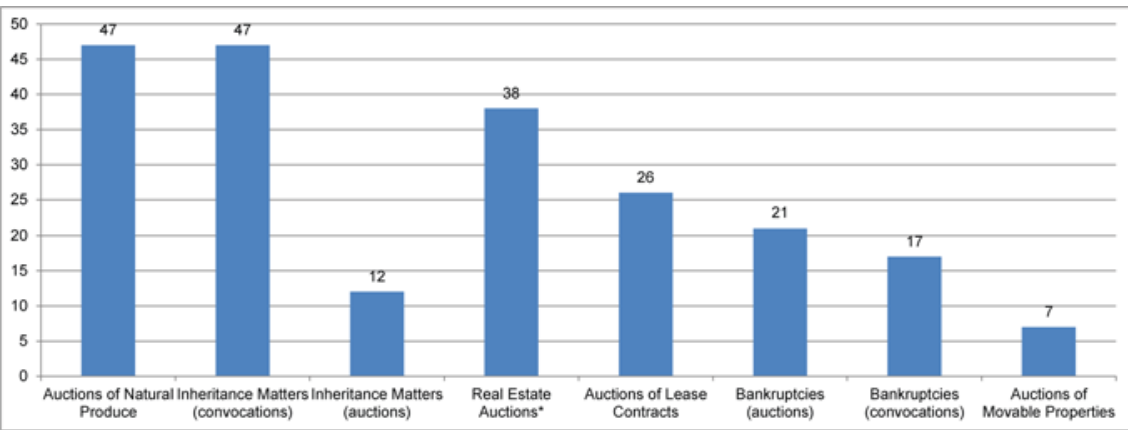

*Former monastic properties: 24; voluntary auctions: 6; undefined: 8.

\section{Bureaucratic Virtues and Enlightened Commitment on Public Display}

Rural administration became visible in the press in many ways. Job applications of aspiring functionaries, for instance, were instrumental in the professionalisation process. The advertisers, who remained anonymous, left the task of establishing contact with interested landlords to the editor's office. These advertisements reveal how ideas of ideal administrators evolved during the period, because applicants described their skills, credentials, and even financial background (required to provide securities) to appeal to prospective employers. A young nobleman, for instance, mentioned a relevant 'internship' and his capability of providing security to obtain an occupation as a seigneurial clerk. ${ }^{57}$ Applicants also described their own character. In one self-description, the aspirant who offered a list of his personal and professional virtues claimed to be righteous, unselfish, mindful as well as loyal, and able to carry out his tasks precisely and swiftly. ${ }^{58}$ While the press served as an intermediate between rural administration and its growing professionalising workforce, it thus also helped to shape an image of the ideal functionary.

Newspapers also testified to the public commitment of officials because they increasingly contained contributions by local administrators. Alois Senitzer, for instance, was an administrator of a state property in a small market town named Aflenz, which had previously belonged to prestigious St. Lambrecht monastery. In this remote and mountainous region he used newspapers as a means to display his professional duties. Incited by his 'human duty', he shared

$5^{8}$ N.N., 'Ein Mann von Rechtschaffenheit', GPN 1 (3 January 1791), [p. S2]. 
his knowledge on the treatment of horses with glandular disorders. ${ }^{59}$ After criticising that most farmers relied on hearsay and information in outdated unscientific booklets, he recommended cheap, secure and predominantly dietetic remedies, proven by his own experience and even experiments. This official's enlightened impetus is also evident in another case where he appears as a supervisor of the local school. In this position, he got into an argument with the parish priest who refused to reveal the teacher's income as a parish clerk. ${ }^{60}$ This additional income would have saved a portion of the salary that the state provided. Later, Senitzer even established a private school for girls, which was widely recommended in $1796 .{ }^{61}$ Instructed by his sister, who also contributed to Habsburg war efforts by providing clothing for military hospitals, girls could learn how to sew and knit. ${ }^{62}$ These activities would improve their families' revenues. Opening hours were flexible, allowing parents to employ their children at home when they needed them. While conservative historians who sided with the church have evaluated state administration in Senitzer's state properties (1786-1802) negatively, the newspapers cited him approvingly. ${ }^{63}$

\section{The Supportive Role of Newspapers}

Joseph II's 'extended freedom of the press' should not only be judged against the background of human rights and 'liberal' motives. ${ }^{64}$ In his authoritative manual, Sonnenfels mentioned newspapers as rumour-mongers as well as objects of censorship, and he bemoaned that most advertising supplements were incomplete, though he conceded that the latter might be valuable if maintained properly and if merchants and craftsmen used them more

59 Aloys Senitzer, 'Eine Kurart für die Drüsen der Pferde', GN 6o (26 July 1791), pp. S595-596.

6o Josef Riegler, Aflenz. Geschichte eines obersteirischen Marktes und Kurortes (Aflenz Kurort: self-publishing, 1990), p. 239. For Senitzer's similar state services in St. Lambrecht: Walter Brunner, St. Lambrecht. Geschichte der Marktgemeinde (St. Lambrecht: self-publishing, 2011), p. 467 .

61 Gubernium Steiermark, 'Bekanntmachung einer schönen Handlung', GPN 42 (26 May 1796), [p. A1]; GN 126 (30 May 1796), [p. A1]; also: Gubernium Steiermark, 'GubernialKundmachung', Graz Ciziten News 119 (20 May 1796), [p. A1].

62 For the patriotic deed: Andreas Leykam, '[without title], GN 32 (6 February 1794), [p. 4].

63 Brunner, St. Lambrecht, p. 467 (who mentions disabled women as teachers); Riegler, Aflenz, p. 47.

64 Wolfgang Duchkowitsch, Absolutismus und Zeitung. Die Strategie der absolutistischen Kommunikationspolitik und ihre Wirkung auf die Wiener Zeitungen 1621-1757 (University of Vienna, unpublished PhD dissertation, 1978), pp. 478-48o (in the chapter "Ausblick auf die Kommunikationspolitik Josephs II"). 
systematically. ${ }^{65}$ More generally, paternalistic Austrian Enlightenment sought to use privileged periodical press products as a channel to reach, to educate, and to manipulate subjects. Apart from forming this official mainstream, competition in newspaper production was explicitly welcomed to boost economy. ${ }^{66}$ For the state, the freed market finally generated revenues from stamp duties which haunted newspaper editors from 1789 to 1791 , from income taxes, and from shipping fees, collected by the state-run post offices. In this competitive situation, advertisements and subscription fees played a considerable role, in particular for newspaper editors who could not dispose of privileges as official provincial newspapers did. This was especially true of $\mathrm{Graz}$ Peasant News as one of the most successful privately funded newspapers.

Ambros aimed at officials with several of his cost-free services. The voluntary inclusion of laws in his newspaper supplements highlights the editor's motives behind the scene. ${ }^{67} \mathrm{On}$ the one hand, the editor obviously strove to complete his newspaper. By including laws into his newspaper, he appealed to subscribers with professional interest for whom the newspapers could serve as a useful collection of provincial laws. ${ }^{68}$ On the other hand, regulations around 1790 provided that newspapers which offered free governmental announcements were granted an exemption from the stamp tax. ${ }^{69}$ As the protocols of the provincial censorship agency show, Ambros indeed submitted a request to receive this tax exemption. ${ }^{70}$ However, the censorship agency had previously stated that newspaper editors in Inner Austria greatly profited from the increase in subscribers due to information on legislation. Therefore, it could not be interpreted as an unselfish initiative worthy of an exemption, and Ambros had to pay the stamp tax.

65 Joseph von Sonnenfels, Grundsätze der Polizey- Handlung- und Finanzwissenschaft, vol. 1 (Vienna: Kurzböck, 3rd edition, 1777), pp. 59, 62-63, 97, 269 and vol. 2 (Vienna: Kurzböck,

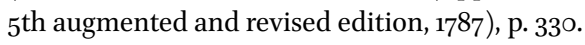

66 Styrian Provincial Archives (Steiermärkisches Landesarchiv, hereafter StLA), Gubernium, Fascicle No. 40-1784-1808 (Box No. 1047), unofficial draft without file number (24 December 1788).

67 Michael Hermann Ambros, 'An Liebhaber der Grazer Bauernzeitung', GPN 99 (12 December 1791), subscription advertisement on a separate sheet: aimed at the general readership esp. for officials: Michael Hermann Ambros, 'Nachricht an das Steyermärkische Publikum', GPN 61 (1 November 1792), p. S467.

68 Cf. N.N., 'Dreyzehn Jahrgänge der Grätzer Zeitung zu verkaufen', GPN 40 (18 February 180o), [p. A3].

69 For the stamp tax in general: StLA, Gubernium, Fascicle No. 40-1784-1808, File No. 13736 ex 1789 (29 March 1789). For the official position on exemptions: StLA, Gubernium, Fascicle No. 40-1784-18o8, File No. 24253 ex 1789 (12 September 1789). 
In late 1791 and early 1792, the compiled lists of food prices from all prominent agricultural and commercial centres of the Habsburg Monarchy constituted a unique selling proposition. It is true that comparable lists of prices in newspapers were not new, but their regional scope had been limited to the country where the newspaper was issued and they had almost exclusively concentrated on grain prices. Therefore the supra-regional endeavour in Graz Peasant News clearly enabled the fight against abusive speculation. When Ambros presented this extraordinary project, he had landowners and their clerks in mind. ${ }^{71}$ The great response of correspondents, especially in the fertile Hungarian holdings of the Habsburg Monarchy, points to the necessity of this initiative in a period of high inflation after a demanding war campaign all over Southeast Europe. The significance of this commitment must not be underestimated, given that Habsburg enlightened despotism tried to control everything from the top and restricted participation from below whenever possible.

Although primarily aimed at the general readership, the editor's excerpts from over fifty advertising papers of the Habsburg Monarchy and beyond are of interest as well, because state properties and seigneuries were well represented. No fewer than 142 relevant notifications (out of 483) can be found, stemming from state properties as far away as Moravia or even from foreign seigneuries in Prussia. This collection of short and essential notices on diverse proceedings might be understood as a supra-regional 'meta-advertiser'. Inheritance cases played a considerable role and were displayed under a special heading. In this connection, Ambros himself commented that convocations of local courts in provincial newspapers were sometimes insufficient in reaching eligible heirs. ${ }^{72}$

The editor also directly addressed officials in paratextual announcements and tried to ease their business, particularly by allowing clearings at the end of a quarter, half or entire year instead of payments for each single announcement which would have been tedious for administrators in remote areas. Specimen copies would be sent to the advertisers, and immediate publication as well as regular repetition was promised. ${ }^{73}$ Right after having overcome the

71 Ambros, 'An Liebhaber', GPN 99 (1791). See: Andreas Golob, 'Frühes Korrespondenzwesen. Michael Hermann Ambros und sein Grazer Zeitungsunternehmen', in Matthias Karmasin and Christian Oggolder (eds.), Österreichische Mediengeschichte, vol. 1: Von den frühen Drucken zur Ausdifferenzierung des Mediensystems (Wiesbaden: Springer, 2016), pp. 134-135.

72 Michael Hermann Ambros, 'Glüksrubrik dem Wohl der Menschheit gewidmet', GPN 85 (24 October 1791), [p. S7].

73 Michael Hermann Ambros, 'An das bekantmachende Publikum', GPN 99 (12 December 1791), [pp. A2-4]. 
ban, Ambros tried to regain officials as important customers. ${ }^{74}$ Later in 1792 , cost-free announcements for all Styrian advertisers would be granted upon the condition that customers would publish their advertisements in $\mathrm{Graz}$ Peasant News first. ${ }^{75}$ The texts of the free advertisements had to be short as well as precise - conditions which excluded official notifications on bankruptcies or inheritance matters. At the same time, the editor confirmed that $\mathrm{Graz}$ Peasant News was the leading newspaper in Inner Austria and in the Habsburg Monarchy as a whole. In this amendment, the editor himself explicitly stressed that officials who represented Styrian state properties could use this service in the ongoing wave of liquidation of former monastic estates. ${ }^{76}$ It seems that this generous offer eventually did not materialise, as comparisons with the three other Graz newspapers in the last two months of 1792 reveal. Advertisers who used more than one newspaper commissioned the press products at roughly the same time in this period, as well. Slight delays or advantages, respectively, can rather be linked to different days of newspaper release. This practice of multiple announcements continued until the local newspaper landscape was reduced from four to two. When the publisher of Graz News announced the unification of Graz Peasant News and Graz Citizen News with his own newspaper in 1796, he explicitly argued that official and private administrations would save a considerable amount of money, because they only had to pay for one announcement instead of three. ${ }^{77}$

Besides certainly extraordinary but only seemingly philanthropic offers, Ambros also appears as a businessman in his newspaper. Advertisements of the editor's own print shop are particularly relevant. Like his colleagues in the printing business, he advertised forms as well as aids for the Josephinian administration, and it seems that this branch of a printer's enterprise was quite important for survival. Apart from Ambros, two of his Graz colleagues combined services for officials with periodical printing as financial backbones, whereas only two further printers also regularly produced books besides newspapers and forms. ${ }^{78}$ In an encompassing list, Ambros himself offered 27 forms

74 Michael Hermann Ambros, 'Nachricht', GPN 16 (24 May 1792), p. S122.

75 Michael Hermann Ambros, 'Nachricht an das Steyermärkische Publikum', GPN 6o (29 October 1792), p. S461.

76 Ambros, 'Nachricht an das Steyermärkische Publikum', GPN 61 (1792).

77 Andreas Leykam, 'Nachricht des Verlegers der Grätzer-Zeitung', GPN $5^{1}$ (27 June 1796), p. 406.

78 Anton Tedeschi, 'In der Tedeschischen Buchdrukerei im grossen von Jakominischen Gebäude Nro. 36o, ist stets zu haben', GPN 1 (3 January 1791), [p. 8], [Anton] Tedeschi, 'Nachricht', GPN 34 (28 April 1791), [p. A2] (printer of the Newspaper for Ladies and Other Women ("Zeitung für Damen und andere Frauenzimmer") 1792 and 1793); Franz Georg Schröckenfuchs, 'Nachricht', GPN 29 (11 April 1791), [p. S4] (printer of Graz Peasant News 
or account books, respectively, and he promised to complete any commission within one week. ${ }^{79}$ Officials in remote areas were even offered preview copies of any item before they decided to place orders. At the end of the announcement on his own account, the editor lastly recommended an Inner-Austrian writing-calendar ("Innerösterreichischer Schreibkalender") which, amongst other things included useful advice on agriculture as well as health care, dates of all fairs in the Habsburg Monarchy and, last but not least, "charts for officials".

Finally, income from advertising sales to rural entities can only be estimated. The fees mentioned offer useful clues. According to the title pages of 1795, "shorter advertisements" cost 34 kreutzer (kr.), whereas $5_{1} \mathrm{kr}$. were due for "longer ones" and "official notifications". When thirteen lines, which equal the shortest official announcement recorded, are proposed as a limit between the two categories, we arrive at an estimate of 91 guilders (fl.) for the year 1791. In comparison to income from subscription fees which yielded at least $7,700 \mathrm{fl}$. in 1788 from subscribers outside Graz alone, this appears to be a negligible lump sum..$^{80}$ The modest figure, however, meant a considerable share of the revenues from advertisements as a whole, second only to contributions from merchants.

TABLE 4.2 Estimated contributions of the advertisers in Graz Peasant News

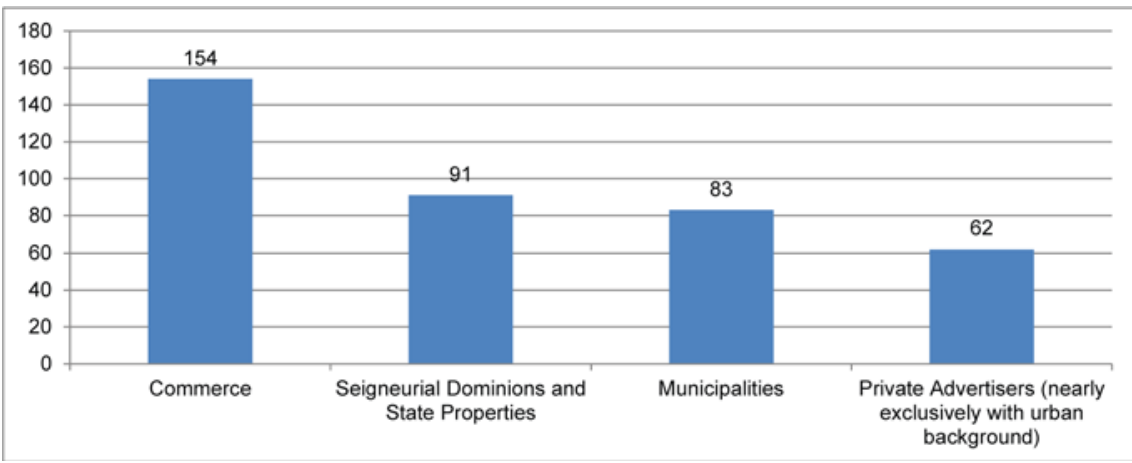

before Ambros opened his own print shop in 1791; from 1792 to 1794 printer of Graz Citizen News). The 'actual' book (!) printers Widmanstetter and Leykam published the Graz Mercury and Graz News, respectively.

79 Michael Hermann Ambros, 'Tabellen-Ankündigung', GPN 64 (11 August 1791), [p. A1].

8o On the basis of data offered by the editor and backed by Graz post office when asked to give detailed information on dispatched newspaper issues for fiscal reasons, cf. StLA, Gubernium, Fascicle No. 40-1784-1808, unofficial draft without file number (24 December 1788). All together 1,100 subscribers received their issues by post in this year. The post office earned one guilder per subscription, seven guilders remained for Ambros (on the basis of the cheapest possible fee). 


\section{Biting the Hand That Feeds: Satire in Graz Peasant News}

While generally supportive of the administration both in its function and in its content, the Graz Peasant News also voiced criticism of Englightened bureaucracy. Such criticism played a remarkable role in satirical literature in the Habsburg Monarchy in the late eighteenth century, the most prominent example being the trilogy of a fictitious judge with the telling name "Schlendrian" (see above, footnote 22). While literary genres of the Josephinian era have been subjected to thorough analysis, the contribution of newspapers in this field of satirical criticism in the Habsburg Monarchy of the 178 os has not been considered yet, because newspapers have only been interpreted as austere newsmongers (what they had indeed been until the mid-178os). Yet the Graz Peasant News evidently partook in the vogue for satire. A satirical mind himself, Ambros predominantly used so-called 'mottos' as teasers for his newspaper issues. In 1791 and 1792, a significant number of them ridiculed different types of notables. These rhymes were critical of wealth without virtue, of priests, physicians and even princes. The seigneurs were also frequently subjected to this mild form of criticism. Occasionally, the mottos alluded to frictions in the relationship between landlords and peasants, the only and indirect traces in the newspaper of officials failing to arbitrate between these parties. ${ }^{81}$

Apart from criticism of the judicial system, which overlapped with the duties of the analysed section of officials, there were only a few directly relevant references. For instance, a leading official answered a recommendation of an aspirant's "head" (that meant his mental skills) with the comment that the young man only needed an arse to sit down. ${ }^{82}$ An inexperienced local judge, just sworn into office, asked God to let him "guess" the best decision. ${ }^{83}$ In another stanza, an administrator pondered on the brains of his donkey, because the animal always found its way back to the stable after having overcome his thirst. ${ }^{84}$ In contrast, it was implied, the notable would get drunk at any given opportunity.

81 For the ideal of "good harmony": Cajetan Wanggo, Gedanken über das Verhältniß zwischen den Gutsherren und ihren Beamten (Graz: Tanzer, 1816), p. 25; also: Cajetan Wanggo, Grundsätze, die Unterthanen zum Gehorsam gegen vorgesetzte Beamte, und überhaupt zur Befolgung der Gesetze anzuleiten. Angehenden Beamten in herrschaftlichen Kanzelleyen gewidmet (Graz: Tanzer, 3rd extended edition, 1816), pp. 11-12, 49-52. The first edition had appeared in 179o. For conflicts see: Winkelbauer, Robot, pp. 181-184.

82 N.N., 'Der Empfehlende', GPN 41 (23 May 1791), [p. 1]. The obscene word was abbreviated as "A ...".

83 N.N., 'Stoßgebeth eines neugewählten Dorfrichters', GPN 9 (30 January 1794), p. 65.

84 N.N., 'Niklas der Verwalter', GPN 25 (25 June 1792), p. 193. 
TABLE 4.3 Notables criticised in mottos, 1791-1792

$\begin{array}{ll}\text { Seigneurs } & 9 \\ \text { Notables in general } & 7 \\ \text { Newly wealthy without virtues } & 7 \\ \text { Princes } & 5 \\ \text { Judges } & 4 \\ \text { Physicians } & 4 \\ \text { Priests } & 3 \\ \text { Officials } & 2 \\ \text { Ministers } & 2 \\ \text { Master craftsmen } & 1\end{array}$

Reports of real incidents were rare, probably due to close observation from the local censorship authority which recorded complaints against Ambros when he expressed criticism against local civil servants. ${ }^{85}$ To cite an extraordinary example, a travelling correspondent portrayed a clumsy, small, obese local official in the northern coastal region of the Adriatic, that is, quite far away from the office of the newspaper. ${ }^{86}$ On a solemn occasion, this disgrace to his profession sought to hold a parade with armed peasants, but miserably failed. After he had given himself liquid courage, he was lifted onto a seemingly dull horse to muster his guard of honour. However, his subjects confused him with their many shortcomings and, eventually, he even forgot the order to fire. Thus, the peasants fired at their own convenience, of course by no means simultaneously. At the second attempt of the gun salute, the by then furious official fell from his shying horse and caused laughter among peasants and audience. Such farcical stories hardly made the newspaper into the watchdog of local bureaucracy.

\section{Conclusions}

This chapter has argued that print was instrumental in the reform of rural administration in the Habsburg Empire around 180o. Print in general and the periodical press in particular did not gain significant momentum in rural administration in the Duchy of Styria before the 178 os. This late impact of the

85 Alluded to in StLA, Gubernium, Index, Fach IVa, entries Nos. 1000 and 4490 ex 1789.

86 N.N., 'Graz den 7. Juli', GPN 54 (7 July 1794), pp. 427-428. 
medium can be explained with reference to general patterns that are representative of large parts of rural Central Europe. Here, the economic environment was markedly different from the interconnected network of commercial cities of Western and Southern Europe in the early modern period that dominate histories of the press. In the second half of the sixteenth century, fierce regional competition had still allowed a Styrian printing business. However, after the Habsburg Counter-Reformation had defeated the Protestant opposition in the Styrian Estates, this potentially promising, commercial source of encompassing medialisation was replaced with a monopoly for a privileged court printer. Only in the early eighteenth century did Graz, as the most important city in the country, reach a level of development which demanded a medialisation of commercial and administrative announcements in the periodical press. In more modest urban settings and in very few large and progressive seigneuries, such developments did not occur before the mid-176os and the late 1770s, respectively.

Eventually, the Habsburg central government initiated the breakthrough of print in rural administration by introducing structural changes and through legal action in the mid-178os. Officials in the countryside were ordered to participate in the increasingly dense network of the periodical press. Obligatory, formal, professional training of seigneurial officials accompanied these ordinances and was embedded in general educational reform. Moreover, the dissolution of monasteries significantly enlarged the ranks of committed Josephinian officials in rural areas. Roughly within a generation, this professional circle embraced print in general to store useful, vocational knowledge and to communicate examples of best practice. The periodical press was not only used in the cases covered by the ordinances of the central government, but also to ease other parts of every-day business, to acquire employment in this expanding section of the rural job market and to publicly present the profession as agents of enlightenment. As a consequence, most inhabitants of the Styrian countryside, and their landlords, experienced the advantages and disadvantages of this way of communication for the first time.

The example of the Graz Peasant News indicates that enlightened Austrian bureaucrats and newspaper editors were mostly allies. Despite the fact that the periodical press also kept a critical eye on their partners, which it expressed in mild satire, they generally supported one another, to their mutual benefit. 


\section{Acknowledgements}

This contribution derives from the project "Participatory Journalism in Michael Hermann Ambros' Periodical Media. Communicating Politics, Education, Entertainment, and Commerce in Central Europe at the End of the 18th Century", sponsored by the Austrian Science Fund (No. P 29979-G28). 